\title{
Human Resource Development and the Formulation of National Economic Policy
}

\author{
Vernon M. Briggs, Jr.
}

One of the more insightful explanations for economic progress in industrialized nations during the last half of the twentieth century has been the recognition of "human resources as the wealth of nations." The notion has long enjoyed a rhetorical appeal by politicians in democratic societies. But awareness that the principle has enormous economic implications for national and international well-being has essentially been a post-World War II phenomena. Increasingly, policymakers in industrialized nations have realized that the human resource development of their labor forces is the key to efforts to address such difficult issues as efficiency, equity, stablilization, and growth. Nations with limited physical resources, such as Japan and Germany, have sustained superior economic performances in this new era largely because they have been forced to develop their human resources. All industrial democracies have come to appreciate the wisdom of Ray Marshall's observation that "developed, educated, motivated people are an unlimited resource ... [while] undeveloped, uneducated, unmotivated people are a monumental drag on an economy in the internationalized information era" of contemporary times. ${ }^{2}$

For most of its history, the field of economics has paid little attention to the contribution of human resources to the production process. Workers were assigned an essentially passive role. It was simply assumed that, since the demand for labor is a derivative of the demand 
for goods and services, the workers could adjust somehow to the technologically imposed requirements of the job. The labor supply was viewed as having a weak influence on job design. During periods in which societies were primarily agriculturally based (as they were during the era of the classical writers from Adam Smith to Karl Marx), the assumption that the labor supply was essentially homogeneous was generally acceptable. Most jobs required little in the way of skill or knowledge and most workers possessed little of either. The same can be said for the job creation process associated with the mechanization of industry during the century following the Industrial Revolution (including the period when classical economics gave way either to Marxist or neoclassical economics depending upon one's politics). The substitution of machinery for the historic dependence by pre-industrial societies on animal and human muscle power resulted in the creation of millions of jobs that required very little in the way of skill or education from the work force. Karl Marx, and later Thorstein Veblen, bemoaned the resulting alienation of workers as the "instinct for workmanship" was gradually factored-out of their working lives. Both described what was essentially the urbanization and proletarianization of the work force because of the onset of the industrialization process.

In the early twentieth century, the addition of continuous process production techniques associated with the advent of the assembly line only exacerbated the dimensions of the prevailing employment patterns. It did not alter them. The economy of the United States was still in its adolescence. Mass production provided a means of producing consumer goods and of offering them at low cost to a consuming public that at the time possessed very few material goods. Except during the years of direct United States involvement in World War I, there was essentially no military budget to consume valuable economic resources. Millions of unskilled blue-collar jobs were created largely in manufacturing, mining and construction. Most required little in the way of human capital endowments. Furthermore, most of the new manufacturing and construction jobs were centralized in the urban centers of the Northeast.

The ensuing labor reform movements of the early twentieth century focused primarily on efforts to remove the sharp edges of the industrialization process. There was no perceived need to develop the human resource potential of the labor force. To the degree that the United States had any human resource policy at the time, it was essentially the open-door immigration policy (until 1924) that admitted millions of unskilled and poorly educated workers to staff the factories, mines, and construction sites, as well as to work in agriculture. The emergence of 
institutional economic thought in the United States during this period (with the exception of Veblen who, like Marx, saw the proletarianization process as inevitably giving way to a new socialist society) was primarily concerned with reforming the existing society. But these reforms-as typified by the humane contributions made by John R. Commons and his fellow members of "the Wisconsin School"-were designed to achieve a "reasonable" and harmonious society. ${ }^{3}$ Commons did not believe in centralized planning. He and his followers thought that evolving institutional arrangements such as trade unionism (with its emphasis on achieving a collective bargaining contract), protective labor legislation, court decisions, industrial commissions with arbitration powers, personnel departments, and shop councils at work sites would provide ad hoc planning mechanisms. These efforts, they believed, would suffice to provide pragmatic ways to address the inevitable human adjustment problems associated with the advances of industrialization. There is mention only by implication by Commons and his associates of any need to focus upon the development of the employment potential of the nation's labor force. Commons's lasting contribution was his advocacy of a real-world problem solving approach as the justification for the study of labor economics. He did not, however, change the view of orthodox economics-that workers were a quantitative necessity but a qualitatively passive agent to the production process.

Likewise, the coming of the "new economics" of John M. Keynes in 1936 did nothing to alter the prevailing perspective. ${ }^{4}$ As revolutionary as were the assumptions and policy prescriptions of Keynes, his analysis had nothing to say about the qualitative nature of the supply of labor. The macroeconomic theory that has subsequently evolved from Keynes's conceptualization was premised upon the singular importance of labor demand. The "employment policy" of Keynes and his followers has meant that the application of fiscal policy measures alone could sufficiently manipulate the aggregate purchasing power of society to stabilize the economy. But in the 1930s, with its mass unemployment and price deflation, there was no real need to worry about human resource development. The primary human resource concern was the under-utilization of the abundant supply of qualified labor that was already available.

\section{The Recognition of the Importance of Human Resources}

Three separate developments have occurred during the post-World War II era that have contributed to the recognition that human re- 
source development may be the key to economic progress in the emerging era of computerization and automatic control. These have been the introduction of the concept of human capital to the study of the labor allocation and income determination process; the linkage of human resource development to economic growth; and the recognition of the growing significance of structural change in the labor market as a specific economic policy issue. Institutional economists have been very wary and openly critical of the human capital approach; they have accepted the findings pertaining to human resource development and economic growth; and they have been instrumental in their advocacy of the need to recognize the importance of human resource development as the key response to structural change of the economy. Each approach warrants brief mention.

\section{The Human Capital of Individuals}

Except for purely classical ideologues, most economists who have studied the labor market of the United States have been dissatisfied with the simplicity of orthodox economics. As the popular saying goes, "when Adam Smith's 'invisible hand' is applied to the labor market, it becomes all thumbs." The labor market is composed of widely differing types of labor demand for various kinds of workers and of a labor supply that consists of individuals with widely differing aspirations, talents, skills, locational preferences, and educational experiences. If classical theory postulates that the labor force is homogeneous, then there is very little for conventional demand and supply analysis to explain. But if both differentiated labor demand and labor supply exist, the explanation of how labor is allocated and rewarded becomes far more complex.

In an effort to salvage a market-oriented analysis, contemporary advocates of neoclassical economics concluded that only slight modifications were necessary in the orthodox perspective. ${ }^{5}$ Their revised view essentially argues that the principle characteristics that differentiate the experiences of members of the labor force are skill and education. Differential economic returns to workers can be explained by the differences in their respective productivities. As there are costs incurred in the process of acquiring marketable skills and knowledge, the attainment of these attributes by an individual can be viewed as an investment in human capital. Proponents of this approach regard it as a positive theory of the labor market that explains how things are-not the way things should be. With this slight adjustment, the advocates 
feel content with the revised neoclassical analysis of how the forces of demand and supply operate in the labor market. Human capital proponents do not believe that human beings should be considered commodities. Nonetheless, they hold that employers actually do view workers as commodities whose labor services are purchased on the basis of their respective human capital endowments. Human capital theory seeks to bridge the gap between income determination and income distribution by asserting that variations in the human capital investments of individuals explain variations in individual income. The policy conclusion is that general expenditures on education and training can enhance the opportunities for higher incomes for labor force participants.

Institutionally-oriented writers have been openly critical of the human capital approach from its onset. Michael Piore, for instance, has claimed that human capital and the study of labor economics are fundamentally distinct. He has said that labor economics "is an applied field concerned with the solution of particular problems" while human capital theory "is applied theory concerned with the application of certain principles." 6 Uniformly, institutionalists, have felt that it is patently naive to believe that the human capital approach is a positive theory that is any more free of normative judgments than any other theoretical approach. ${ }^{7}$ But more substantively, critics have attacked the simplicity of the human capital approach-like its broader neoclassical paradigm - for its avoidance of any recognition of the significance of complex institutional practices and historical factors that influence labor market operations. ${ }^{8}$ There is no allowance made for the ways that societal institutions (for example, schools, businesses, unions, government, or the military) can limit through their customs, practices, and policies the efforts of individuals to maximize opportunities to improve themselves. Nor is there any recognition of the historical barriers that have been placed in the paths of subgroups of the labor force to attain levels of human capital or to apply equally those human capital attributes that they do possess. Studies, for example, have found that many such workers often already have human capital endowments that exceed the limited range of jobs that are generally available to them. ${ }^{9}$

Lester Thurow, who once was an avid advocate of the human capital approach, has subsequently become one of its sharpest critics. ${ }^{10}$ Thurow notes that the labor input to the production process is so "peculiar" in its characteristics that it simply cannot be analyzed according to the same criteria applicable to physical factors of production. Human beings have preferences that are formed in a social environment. These preferences foster likes and dislikes that are often interdependent. 
Thus, when human beings are involved, their behavior cannot be fully judged by simply using income as a measure of economic performance or behavior or as an indicator of satisfaction. In addition, the productivity of human beings often depends on personal motivation and effort. It is not technologically determined. Likewise, human capital cannot be separated from its owner (for instance, to earn a football player's wage, you must be able to excel in playing football). Further, whereas physical capital can only produce goods and services, human beings both produce and consume human capital (for example, significant consumption expenditures are made for improving health, acquiring education, or searching for a better job). Thurow also notes that many important decisions concerning human capital acquisition by individuals are made by other people (that is, parents and society) and, because human beings are mortal, the age and physical condition of an investor in human capital has much to say about the possibility of acquiring and using particular skills and education. There is a high premium placed on making many human capital decisions early in one's life, whereas such considerations are unimportant for investors in physical capital. Human capital, it turns out, often represents a collection of assets rather than a single asset. Moreover, not every investor in human capital has the same set of production techniques (some individuals have natural talents while others cannot acquire the same abilities no matter how hard they try or how much they spend). Thus, Thurow concludes "a human capital model of investments can be constructed but when it is completed it will have little relation to the model used for physical investments." II

Consequently, institutionalists have seriously questioned the appropriateness of the human capital approach with its feedback to traditional neoclassical analysis. ${ }^{12}$ The issue involves much more than theoretical carping. Although human capital theory seems logical in its surface reasoning, it is flawed in its diagnosis of labor market outcomes and deficient in its application to the experiences of major subgroups of the labor force. With respect to diagnosis, it places full responsibility for differential market outcomes on individuals for their assumed differential investments in their human capital. It postulates, for example, that the poverty, underemployment, and unemployment of lowincome minority workers is their fault (that is, they underinvested) when, in fact, the opportunities for self-improvement may have been inadequate or unavailable. By also attempting to link the education and training of individuals to income rather than to productivity, it is impossible to determine if higher earnings are the result of actual human 
capital endowments or of the mere possession of certain job credentials. In other instances, persons who already possess adequate skills and educations are denied equal opportunities to apply these abilities. The theory cannot explain why a subgroup such as Hispanics has a considerably higher income than do blacks even though blacks have significantly higher educational attainment levels than do Hispanics. The same can generally be said for the earnings experiences of many women relative to many men. Critics of the human capital approach assert that the explanations are more likely to be found in institutional practices and historical influences in the labor market that cause, rather than merely reflect, the differential experiences of certain individuals and of major groups within the labor force.

\section{Human Resources and Aggregate Economic Growth}

Most economists with differing intellectual orientations agree with the conclusions from studies relating human resource development with aggregate productivity increases and economic growth. Relying upon the seminal work done by Edward Denison, it is now clear that the growth of the U.S. economy stems from the contributions of the nation's human resources. ${ }^{13}$ Of the six groups of sources that he identifies as making positive contributions to U.S. economic growth from 1929 to 1982 , the labor inputs account for nearly half -47 percent-of the growth rate (34 percent came from an increase in the amount of work done because of the numbers, working hours, and characteristics of the workers, while an additional 13 percent is attributed to the increase in the level of education). If advances in knowledge (which added 26 percent to the growth of the economy) are included among the human resource contributions, the total human resource contribution increases to 73 percent. A similar study by Anthony Carnavale in 1983 found that 75 percent of the improvement in productivity in the United States since 1929 can be attributed to human resource development activities such as on-the-job training, education, formal training and health. ${ }^{14}$ Thus, while economists in general and public policymakers in particular have focused upon physical capital as the explanation for long-term economic growth, it has actually been human resource development that has been the major contributor. Denison, for instance, found that increases in physical capital added only 17 percent and land improvements added zero to long-term economic growth.

Thus, the idea that human resources are a nation's most important asset is no mere political cliché. It is a fact of economic life that de- 
serves prominence in policy formulation. As will be discussed subsequently, recognition of the necessity to focus economic policy upon human resource development is a relatively recent concept as has been the process of forging the institutional practices and organizations required to foster this relationship.

\section{A Response to Structural Change}

A major contribution that institutional economists have made to directing public attention and policy toward the necessity to adopt a human resource strategy has come from the contention that the employment structure of the U.S. economy since the end of World War II is being radically transformed. The causes are diverse but, in the main, they stem from rapid changes in technology; the fact that science itself has become a major source of innovation; enhanced foreign competition; substantial increases in the size of the labor force; dramatic changes in the gender and racial composition of the labor force; major shifts in consumer tastes away from goods toward services as revealed by their emerging expenditure patterns; the revival of mass immigration; and the accelerated growth in governmental expenditures on national defense. ${ }^{15}$ The resulting influences have caused major industrial shifts of employment patterns from goods production to the provision of services; of occupational patterns from blue collar to white collar employment; and geographic shifts from rural to urban areas, as well as from the historic employment concentrations in the urban Northeast to new concentrations in the urban Southeast and urban Southwest.

Many observers believe that these shifts in employment patterns are responsible for the pronounced secular rise in the "prosperity unemployment rates" that the nation has sustained since the end of World War II (that is, every period of prosperity-with the sole exception of the years during the height of the Vietnam War in the late 1960s-for the past forty years has been accompanied by a higher level of aggregate unemployment than the previous period). Moreover, the unemployment experiences of subgroups of the labor force have not been evenly distributed. Youths and minorities, have, for example, sustained significantly higher unemployment rates than have been revealed by the rising aggregate unemployment measure. The same can be said of many workers in selected inner-cities and rural areas. Those workers with low levels of education and training, inadequate work experience, and those from groups that have endured past experiences with discrimination have had the greatest difficulty finding adequate employment and comparable income opportunities. 
Recognizing the emergence of a secular increase in unemployment, however, has been easier than securing agreement among economists about what is causing the phenomenon or what to do about it. ${ }^{16}$ Since the 1930s, Keynesian macroeconomics has sought to lay claim to the resolution of problems of economic stabilization. Thus, macroeconomists asserted in the 1960 s that the problem was inadequate demand that required a fiscal policy solution (that is, reliance on a massive tax cut)..${ }^{17}$ Likewise, during this same period the monetarists, led by Milton Friedman, boasted that they had the proper policy panacea. ${ }^{18}$ These two policy approaches vied for support from mainstream economists. ${ }^{19}$ But when substantial rates of inflation and unemployment occurred simultaneously in the 1970s, both schools of thought were intellectually stymied and forced to revert to baroque refinements of theoretical principles rather than to confront directly the economic problems of the times. Nevertheless, the teaching of economics in the United States has been based upon the contention that fiscal and/or monetary solutions are the proper responses to changing economic conditions in the labor market.

In contrast, a number of labor economists contended throughout this era that it was the changing structural conditions in the labor market that were the explanation for the deterioration of employment conditions. These structural factors meant that the supply of labor could not adjust automatically to the changing character of labor demand. Hence, they contended that these structural conditions had to be squarely addressed. ${ }^{20}$ They prescribed interventionist human resource policies that were directly focused on facilitating the labor adjustment process. Advocates of human resource development have not attacked the need to adopt parallel policies designed to stimulate the demand for labor. But they have claimed that exclusive reliance upon such measures is likely to be insufficient to provide full employment for an economy in the midst of structural transformation. ${ }^{21}$

Ironically, Keynes was fully aware of the limitations of his proposals. He stressed the fact that his analysis was essentially a short-run diagnosis. It was based on the assumption that the size of the labor force, the capital stock (both human and physical), the state of technology, the degree of competition, and the tastes for consumption of goods and services are all assumed to be constant. ${ }^{22}$ In the short run, such assumptions may be acceptable, but over the long run they obviously are not. Keynes clearly recognized this limitation. He labeled these parameters as composing the "social structure" that "determines the distribution of national income." ${ }^{23}$ In other words, he recognized that changes in these structural conditions require policy responses other than fiscal 
policy. But the modern-day disciples of Keynes have overlooked his expressed warnings and have sought to convert his analysis into a longrun prescription for achieving stabilization. ${ }^{24}$ They have acknowledged the existence of structural problems but they have contended that there is always some element of structural problems in any dynamic economy. They deny that these conditions have worsened in the contemporary era. Much the same can be said for the monetarism of Milton Friedman. It too is a single remedy approach. It simply assumes (or asserts) that a competitive domestic economic system with flexible international exchange rates must only adhere to a steady growth in the nation's money supply to achieve non-inflationary full employment. Labor force adjustment is assumed to be automatic. Thus, little mention is made by either macroeconomists or monetarists of the supply of labor and how it might adjust to widespread and sustained structural changes.

Despite the confidence-or arrogance-of both macro and monetarist economists that demand policies alone can guide the economy, labor economists of an institutional bent have not been convinced. They have argued that the structural changes in the economy require specific labor market responses. It is argued that in the emerging economic environment, the types of jobs that are most rapidly increasing in number are those that place a premium on skill and education; those that are disappearing are the ones that require little in the way of human capital endowments. Moreover, the geographical distribution of the growth of jobs has been uneven. Thus, it is to be expected in such dynamic circumstances that unemployed people and vacant jobs can coexist on both a short- and long-term basis. ${ }^{25}$ Thus, there has been support for a policy approach that focuses on labor market policies-such as occupational training, re-training, up-grading, work experience, education (at all levels), improved labor market information systems, and voluntary labor relocation programs. There has also been growing recognition of the employment significance of such other critical areas of public concern as health, welfare, housing, speech therapy, counseling, social rehabilitation, child care, legal services, and transportation. The package of reforms also has included measures to assure equal employment opportunity practices. Thus, the overall objective has been to develop public policies that are intended to enhance the employment potential of labor force participants. As opposed to the general approach of fiscal and monetary policy, the human resource approach seeks specific remedies for specific individual circumstances. Different groups in the labor force have different needs. Hence, a menu of policy options needs 
to be offered. By introducing the concept of "employability" into the labor policy lexicon, it has also been implicitly recognized that no longer are such issues as unemployment, underemployment, and poverty to be considered the sole province of economists. Other disciplines and professions also have key roles to play in the policy formulation and application processes.

Throughout the 1960s and 1970s, the growth of human resource policy was strongly supported by governmental action despite the reticence of many mainstream economists about the need for a human resource strategy. Congress and a series of administrations (Kennedy through Carter) were openly supportive of providing programmatic substance to these ideas. In addition, the U.S. Department of Labor during this era undertook a massive research agenda to spawn policyoriented programs, to sponsor demonstration projects, and to create an evaluation system to assess the effectiveness of the results. ${ }^{26}$ It was a period of social experimentation that, as one might expect, included both successes and failures. ${ }^{27}$

In the early 1970s, still another tact was added to the human resource program endeavors. It was the revival of direct job creation. At first the support was based on the fact that job creation could be used as a countercyclical employment device just as it had been during the New Deal era of the 1930s. But by the mid-1970s, such programmatic actions were also viewed as having a counterstructural potential. Namely, there are certain subgroups of the labor force that have difficulty finding jobs even during periods of general economic prosperity. Providing jobs in the public sector could serve as a means of on-the-job training for persons who lacked both skills and work experience. The jobs that were provided could also be designed to provide needed public services that were generally underfunded (in urban areas) or unavailable (in rural areas). Moreover, during the period when the nation was confronted with both inflation and unemployment, job creation programs could be targeted precisely to those groups and regions that had higher-thanaverage unemployment rates so as to provide needed jobs while not contributing to inflationary labor market pressures. Despite political criticism of some of the administrative aspects of these efforts, the research studies of the economic effectiveness of these job creation programs were uniformly favorable. ${ }^{28}$

With the election of the Reagan Administration, however, this era of public support for interventionist human resource strategies essentially came to an end-or at least a pause. The Reagan Administration has sought to reduce domestic social expenditures in order to enhance 
the nation's defense posture. All public sector job creation programs were terminated and expenditures on publicly supported training programs were sharply reduced. Education programs, especially those designed for low-income students, were curtailed. For awhile, there were even attempts to abolish the Department of Education from the federal bureaucracy. As for economic policy, the administration fell back upon conventional macroeconomics as embodied by a series of massive tax cuts plus pursuit of a more competitive domestic environment (as manifested by efforts to de-regulate the economy and to pursue a freetrade international policy) to resolve employment problems. ${ }^{29}$ In the wake of these endeavors, unemployment soared in 1981 and 1982 to the highest levels experienced since the 1930s (almost 11 percent). Even when a "recovery" did begin in 1983, the aggregate unemployment rate remained in excess of 7 percent throughout the mid-1980s. Unemployment rates for minorities and youths soared to astronomically high rates throughout this period.

It is likely that the nation is going to pay a high price for the interregnum in public support for human resource development. Unlike fiscal policy actions and money supply manipulations that can be altered in relatively short order, human resource policies and programs require long-range planning and continuity in financial commitments. Training and educational institutions involve the need for facilities, materials, equipment, staff, and administrators. But the most difficult problem to overcome is the fact that it takes highly trained people to train and to educate the untrained and the uneducated. Erratic support for human development programs can only make more difficult the task of attracting and retaining qualified trainers and educators. The same can be said for the parallel need to develop qualified program administrators and to attract a cadre of academic scholars to the field to generate problem-solving ideas and to assess programmatic effectiveness.

If the structuralists are correct in their assessment, it is likely that public support for this approach will again revive in the near future. To paraphrase Winston Churchill, it is hoped that the Reagan Administration's disinterest in human resource development is not the beginning of the end but, rather, merely the end of the beginning of efforts to adopt an active human resource policy at the national level. The remainder of this essay is devoted to outlining the course that a renewed human resource approach could assume.

\section{Dimensions of Human Resource Development}

There are three separate policy approaches to the study of human 
resource economics. One pertains to the quantitative dimensions, which are concerned with the aggregate amount of human resources that are actually available and utilized to produce the nation's goods and services. The second is the qualitative dimension, which is concerned with the opportunities for development of the latent employment potential of the individual, as well as the collective employment capabilities of society's available human resources. The third is the necessity to assure there are no artificial barriers imposed on the labor market that prevent equal opportunity both to access to the societal institutions responsible for human resource development and to employment in the jobs that allow persons to apply their acquired abilities.

\section{The Quantitative Dimension}

The quantitative dimension of a nation's human resources are transmitted to the economy through its population by means of participation in the labor force. The population is composed of those people who are born within the country plus the net difference between those who immigrate minus those who emigrate. In the United States, immigration has, since the mid-1960s, again emerged as a significant contributor to the nation's population growth. As the demographer Leon Bouvier has recently observed "immigration now appears to be almost as important as fertility insofar as U.S. population growth is concerned." ${ }^{30}$ Thus, in the United States (but unlike most other industrial nations), immigration is of major contemporary consequence. ${ }^{31}$ Although there is emigration from the United States, no such data has been collected since 1958. There is no question, however, that immigration exceeds emigration by several multiples, so that net immigration is known to be positive even though it cannot be specifically measured.

The Population-Labor Force Issue. The conversion of some portion of the population into an available labor force is measured by statistical definitions that measure availability and not well-being. ${ }^{32}$ This means that there is a minimum age set for a person to be counted in the labor force. There are also standards that are set to determine those persons of labor force age who are not confined in institutions, and who are able, available, and actively seeking employment. Those who find work for a defined minimum number of hours are counted as being employed; those who meet all other standards for job search but who do not meet the minimum hour requirement are unemployed.

Thus, at any given time, there is some reserve portion of the population of labor force age who constitute potential human resource contributors to production of output for the economy but who are not 
being utilized. Most serious of these are those persons who are officially classified as being unemployed. The inability of an economy to provide employment for available workers represents the epitome of human resource inefficiency. Thus, one key aspect of national human resource policy must be to press for policy measures that are designed to obtain full employment. Consequently, as indicated earlier, fiscal and monetary policies that are specifically designed to maintain a high level of labor demand do have a quantitative human resource dimension: namely, the utilization of all available human resources already qualified to fill any jobs that are created as a direct consequence of these policies under changing economic circumstances.

The issue of the underutilization of human resources also has efficiency overtones. Of most concern are the problems of "discouraged workers" (that is, persons who give up active job search but who want to work if they thought they could find employment) and involuntary part-time employment (that is, persons who work part-time but who want to work full time). The former are not counted as being employed or unemployed, while the latter are counted as being fully employed. There is also the issue of underemployment-the situation wherein workers are employed in jobs that require skills and education below those that the workers already possess. Presently there is no measure of this underemployment because the concept is not easily quantifiable. The difficulty of measurement does not mean that the problem is unimportant. In fact, there are significant signs that underemployment is widespread in rural areas and in many inner cities. ${ }^{33} \mathrm{~A}$ comprehensive human resource strategy must include efforts to reduce all of these categories of underutilization and underemployment.

Although quantitative measures of human resources focus on availability, full employment and full utilization of available human resources may still be insufficient goals. Available measures of human resource utilization do not relate income and earnings to employment. Consequently, it is possible for the spouse of the highly-paid president of General Motors to be unemployed (and, thus, be a subject of quantitative concern because an available human resource is not being employed), while a fully employed family head may be unable to earn a salary sufficient to pull his or her family above a poverty level (but not be a subject of specific quantitative concern because the resource is counted as being employed). Hence, a complete human resource strategy should look beyond mere utilization measures to examine the economic welfare of the employed human resources as well. Proposals to link employment and earnings in order to acquire a measure of actual 
economic "hardship" have been made but, to date, they have not been accepted as an official policy concern. ${ }^{34}$

The Immigration Issue. In those few countries of the world-of which the United States is one-that continue to accept significant numbers of new immigrants each year, immigration constitutes an important aspect of human resource policy. With the exception of Israel, which uses immigration policy as a means of national security and for religious acommodation purposes, most of the remaining nations use immigration to meet specific labor market needs (for instance, to meet skill shortages or to settle unpopulated areas where worker shortages exist). In these cases, there is also a tendency (as in Canada) to annually adjust the number of immigrants to be admitted on the basis of aggregate labor market conditions (when unemployment is low or declining, immigration levels are allowed to increase; when unemployment is high or rising, immigration levels reduced). In the case of the United States, however, immigration policy-for a number of unique institutional reasons-has been allowed to function independently of its economic consequences. ${ }^{35}$ It has been allowed to become a purely political policy. Not only is mass abuse of the admission system tolerated by illegal immigration, but the legal system is predicated largely on the basis of family reunification rather than on demonstrated labor market needs. Moreover, legal admission levels are fixed so that there is no effort made to relate the number of immigrants admitted each year to prevailing economic conditions. If annual immigration flows were of minor importance, there would be little reason for concern. But as immigration accounts for at least one-third of the annual growth of the U.S. labor force in the 1980 s, immigration is not a subject of minor human resource consequence. Comprehensive reform of the entire immigration policy of the United States is a contemporary imperative.

\section{The Qualitative Dimension}

In a period of economic transformation, democratic nations like Germany, France, Sweden, and Japan have recognized the need for an "active" human resource policy to complement efforts to achieve full employment of all available human resources. ${ }^{36}$ Experience has demonstrated to the governments of these nations that labor market adjustment to rapidly changing industrial, occupational, and geographic employment patterns cannot be assumed. The United States has taken tentative steps in this direction, but, as will be discussed below, has tended to focus its efforts on passive policies designed to help those 
"left behind" by economic change. Helping the economically disadvantaged is a noble and a necessary aspect of a human resources development strategy, but it is an incomplete approach if similar undertakings are not available to all income stratums of the labor force who need assistance.

The overarching difference between the state of human resource development policy in the United States and that of other major industrial democracies is philosophical. In these other nations, the underpinning of their human resource endeavors is the belief that all accidental victims of social and economic change or of cyclical fluctuations in the economy are a societal responsibility. It is society's obligation to train (or retrain), to educate (or reeducate), to relocate, or to compensate those workers who find themselves unemployed or underemployed through no fault of their own. In most instances, these nations have adopted some form of national economic planning or industrial policy that includes necessary labor market adjustment policies as key elements. But, in the United States, the tendency is to place the responsibility on individuals and local communities to respond to these changing economic conditions on their own. There is little or no economic planning (except in the special areas of national defense and national highway construction). There is an aversion to economic planning in general and to human resource planning in particular. Reliance upon individual and community adjustment to the conditions of the marketplace remains the policy norm-especially in the 1980s. There is periodic political talk during election years about the need to re-order national "priorities" (which is precisely the language embodiment of the planning ideal) but there have been no steps at the national level to formalize the procedures necessary to establish and to achieve any set of national priorities. The political power (or lack of it) of vested interest groups to exert lobbying strength to achieve ad hoc objectives remains the modus operandi in the United States for setting and pursuing most non-defense related economic objectives.

The exception to this generalization about interventionist human resource policy has been the limited and piecemeal programs enacted between 1961 and 1981. During this period, the federal government initiated a variety of endeavors to directly assist in labor force adjustment. In response to a campaign pledge made by President John F. Kennedy, legislation was passed in 1961 designed to assist distressed geographic areas (that is, areas with above average unemployment rates). Included in the assistance package were federal funds to provide occupational training to citizens who might be hired by private sector 
enterprises that agreed to locate in these designated areas. This legislation was the "nose under the tent." It opened the door for a virtual plethora of human resource development legislation. These initiatives included overhauling existing vocational education and vocational rehabilitation programs, expanding and opening up apprenticeship training to minorities and women, providing federal funds to aid elementary, secondary, and higher education, creating health care programs, establishing nutrition and food stamp programs, providing preschool education to children of low-income families, as well as remedial adult education programs, and initiating economic development assistance to regions, communities, and neighborhoods.

In the training field, one of the most ambitious undertakings was the adoption of the Manpower Development and Training Act (MDTA) of 1962 and its subsequent liberalizing amendments. This legislation is of special interest because it was originally enacted in direct response to fears that rapid technological change (caused largely by automation) was a major explanation for structural changes in employment patterns. ${ }^{37}$ This pioneering legislation was primarily designed to provide occupational retraining at the public expense for displaced workers to find private sector employment. In a way, it was intended to be a new form of social insurance for semi-skilled persons with prior work experience. With the coming of the Vietnam War, however, the employment patterns that had caused this concern were at least temporarily reversed. Both manufacturing sector jobs and blue collar occupations that had been declining for over a decade, were revived because of the sharp increase in defense and defense-related spending. The original clientele for MDTA, therefore, appeared to have vanished.

In the meantime, however, the civil rights movement had come into full blossom with the passage of the historic Civil Rights Act of 1964. After the initial euphoria had passed and the political and social barriers to black participation in American society had dissipated, the monumental challenges to the achievement of economic equality became starkly vivid. The concept of equal employment opportunity embodied in the Act assumed that minorities were already qualified for available jobs. Some were. But too often, the legacy of past denial of opportunities to acquire sufficient human resource preparation had left many from these groups unqualified, uninformed, unaspiring and disproportionately concentrated in declining industries and occupations. In the wake of the obvious need to address the massive human resource development deficiencies that had been forced upon the black population by past de jure and de facto discrimination, the Johnson Admin- 
istration shifted the focus of MDTA in 1967 to serve the employment needs of the "economically disadvantaged." This was an historic turning point. Rather than returning to serve the broader needs of the labor force when the Vietnam War was over and the structural changes in the economy once more revealed themselves, these publicly supported training programs continued to focus on the employment needs of the "economically disadvantaged." Ostensibly, the training programs were for adults and youths from low-income families without regard to race. But as minorities in general and blacks in particular were disproportionately concentrated in the low-income population, they dominated the clientele.

In the process of concentrating on the employment needs of the "economically disadvantaged," however, these remedial programs acquired a stigmatizing image that implied that human resource programs were only for those people unable to help themselves. As a consequence, when the Reagan Administration came to power in 1981 with a determination to reduce federal spending on social programs, these programs did not have a politically powerful enough constituency to withstand the assault. The programs were drastically reduced in both their substance and in their level of financial support. Had the full potential of a national human resource development policy been in place to assist all income groups in need, it is unlikely that this dismantling process could have been accomplished.

Assuming that the federal government may someday renew the process of actively supporting human resource development, the qualitative dimensions of a human resource strategy should embrace three concepts: salvage; a preventive maintenance; and long-run educational development.

The Salvage Function. Despite the aforementioned efforts to reduce their numbers, there remain a number of individuals and subgroups of the population that are unprepared to find employment on a regular and self-supporting basis. In many instances, it is necessary for a civilized and generally prosperous society to financially support these persons-usually, however, at only marginally sufficient levels. Without targeted programs to develop their human resource abilities, these people are essentially doomed to play out their lives in poverty. There are also other persons who lack sufficient skills and education (because opportunities to acquire them were unavailable or inadequate, or because of a personal failure to take advantage of opportunities that did exist), which means that they are often forced to survive in the sizeable "irregular economy" of narcotics dealing, prostitution, gambling, and 
theft. Not all poor people or all "street hustlers" are amenable to a rescue attempt by human resources programs. But as long as there are sufficient numbers, a salvage strategy to provide a life-line of opportunity to prepare for legitimate employment is in order. For not only is it a socially worthy undertaking to reduce human suffering but, as indicated earlier, there is also the pragmatic economic reality that uneducated and poorly skilled workers can become "a monumental drag" to a post-industrial society.

Although a number of labor force issues could be cited where a salvage response seems warranted, three illustrative problems stand out in the mid-1980s: the declining black male labor force participation rate, the growth in the number of female-headed households and the feminization of poverty, and the mounting level of adult illiteracy. The corrective factors associated with each of these concerns are unlikely to be resolved by reliance on standard fiscal and monetary solutions. Each of these deserves a brief elaboration.

Historically, the labor force participation rate of black males exceeded that of white males for every age cohort. Beginning in the 1950s and since then, the reverse trend has developed. Consequently by 1985 , the overall black male labor force participation rate was 70.8 percent while the comparable rate for white males was 77.0 percent. All things being equal, there is no reason why white males should now have higher participation rates for every age cohort than do black males or why white males should have a considerably higher overall rate. But, of course, all things have not been equal. Black workers are clustered disproportionately in declining industries in the inner cities of about twelve major urban areas, in addition to being scattered throughout much of the rural South. Jobs in general are scarce in these areas. But jobs are especially hard to find if one has few skills and a poor education and if there are limited opportunities to acquire or to develop latent abilities. Too often, this has been the case for black males. The process of finding a job that can provide adequate income is made more difficult if there are lingering practices and practitioners of racial discrimination. Under these conditions, an inordinate number of black males apparently have despaired from seeking work in the regular economy. There is, of course, an ominous societal implication to the secular decline in their participation rates. If adult black males are not at work, or in school, or in the military, what are they doing to survive?

The second group of special concern is female heads of householdsespecially those with families below the poverty level. In 1985, 10 million families were headed by females (because of divorce, separation, 
widowhood, or having children born out of wedlock). Of these, 6 million had children under the age of eighteen living with them. One of every three families headed by a woman was living in poverty (compared to one of thirteen for all families). In the labor market, the female single parent is often plagued by educational deficiencies, high unemployment, and low earnings. It is unlikely that many of these female family heads would be able to improve their employment and income opportunities without specific programmatic assistance.

Overlapping the issues of the nonparticipation of black adult males and the employment difficulties confronting female single parents is a third salvage problem: adult illiteracy. Although the 1980 Censusrelying primarily upon written responses to a written questionnaireconcluded that the nation is almost 100 percent literate, these findings have been seriously questioned. Indeed, based upon studies that have focused squarely upon the issue of literacy, the U.S. Department of Education reported in 1983 that 23 million adults are totally or functionally illiterate and that another 23 million adults are only marginally literate at best. ${ }^{38}$ Other studies released in the early 1980 s have placed these numbers even higher. ${ }^{39}$ The situation is believed to be so severe that the National Commission on Excellence in Education, appointed by President Ronald Reagan, concluded its 1983 comprehensive report by saying that the future welfare of the nation is "in peril" and chose to title its report, Nation at Risk. ${ }^{40}$

The economic consequences of mounting levels of adult illiteracy among the labor force are much more severe in the emerging serviceoriented society than was the case when the goods-producing sector dominated the employment generation process. The bulk of employment opportunities provided by the goods-producing industries in the first half of the twentieth century did not require much in the way of educational and verbal skills from its jobs seekers. But the service economy is based much more upon verbal than manual skills. Thus, the literacy gap has emerged at a time when changes in the labor market are placing a premium on communication skills. Service industries and technologically-oriented businesses require workers to handle comprehensive tasks that are often based more on reading, writing, and listening than on manipulative skills. Thus, there is an inherent threat to the evolving viability of the economy because of widespread adult illiteracy. It entails more than a loss in potential worker productivity because of the limited availability of employment opportunities for such people. Adult illiteracy also contributes to the incidence of workplace accidents, the provision of poor quality products and services to 
customers, and the loss of management and supervisory time. Even the U.S. Department of Defense has been forced to spend "thousands of dollars to convert weapon manuals into easy-to-read comic books for military recruits who are expected to handle complicated equipment." ${ }^{41}$ Hence, even the nation's ability to adequately defend itself may be at stake.

As if the number of functionally illiterate adults were not bad enough, it is estimated that their ranks are actually swelling by about 2.3 million persons a year. ${ }^{42}$ Growing adult illiteracy has been attributed to the declining standards of the nation's educational institutions from elementary through college levels. Another cause has been the epidemic of teenage pregnancies over the past decade, which contributes to the school "drop-out" problem. Whatever the reasons, it is estimated that about one million teenagers leave schools each year without sufficient literacy skills. But the largest source of growth in the ranks of the functionally illiterate is immigrants who cannot speak English and who, in many cases, are illiterate in their own native language. This is especially the case with would-be workers who enter the nation illegally from Mexico and the Caribbean Basin. It also applies to many of the recent refugees admitted from Southeast Asia and from many of the post-1980 asylees and asylee-applicants from Cuba, Haiti, El Salvador, and Guatemala. ${ }^{43}$

Thus, there is an urgent need to undertake a national program geared to the attainment of educational competency. It was estimated that in 1985 about 75 percent of the unemployed persons in the United States have inadequate reading and writing skills. ${ }^{44}$ Until these basic deficiencies are addressed, it is very difficult-if not imposssible-to provide the related skill acquisition needs of this significant segment of the adult population. It is also doubtful that any reasonable application of traditional monetary or fiscal policy could alone create sufficient employment opportunities to employ so many illiterate persons.

The Preventive Maintenance Function. In a period of labor market transformation, there is an acceleration in the process by which traditional industries and occupations decline and new ones rise to take their place. As discussed earlier, there are multiple new forces affecting employment patterns in the United States. The service sector of the economy has soared from accounting for 31 percent of the employed labor force in 1900 to 69 percent of employed labor force in 1984. The Bureau of Labor Statistics estimates that 90 percent of the growth in employment between 1985 and 1995 will be in the service sector ${ }^{45}$ But there is a pervasive myth that must be debunked: it is that service sector jobs 
are dead-end and low paying. Some are, of course, but so are some in the goods-producing sector (for example, in agriculture and textile manufacturing). The reality is that 80 percent of the professional and managerial jobs in the entire economy are to be found in the service sector. While it is true that there are growing service employment opportunities in such low-paying industries as fast-foods and nursing home care, there are also substantial employment increases being realized in high-paying jobs in computer services, legal services, and advertising, as well as average-paying jobs in insurance, wholesale trade, and auto repairing. ${ }^{46}$ In general, the shift to a service-based economy will lead to an upgrading of the skill and educational requirements of the labor force from what hitherto existed.

The rapid shift to a service economy also has implications for the location of jobs. Goods-producing industries tend to cluster in specific geographic areas. But the key characteristic of services is that they must be produced locally. Thus, the shift from goods to services has contributed to the de-centralization of employment away from its historic concentration in the urban Northeast to other regions. Shifting national defense expenditures have also affected the geography of jobs. Historically, through the Korean Conflict of the 1950s, major non-personnel defense expenditures were made on steel and wheeled vehicles. Since the 1960s, however, the bulk of non-personnel expenditures has shifted towards missiles, rockets, and aircraft. These weapons often require that some phase of their construction be accomplished out-of-doors and that they be tested either over water or in remote areas with low populations. The result has been a shift in employment opportunities to the Southeast and Southwest.

In an environment of rapid shifts in employment patterns, it is necessary to recognize that both job and occupational changes will occur frequently over one's working life. Indeed, a typical worker entering the labor force in the mid-1980s can be expected to change jobs six or seven times and to change occupations three times over his or her working life. In this context of flux, there is a need to have in place a human resource system that can provide job retraining, up-to-date labor market information, ample opportunities for educational upgrading, and relocation assistance to promote the readjustment process for those who cannot easily, if at all, make these transitions. The system should not just help the working poor. It should also be designed to assist all income groups who become vulnerable to unemployment.

Traditionally, decisions pertaining to selecting careers, receiving training, securing education, and locating jobs have been left to indi- 
viduals. But in a climate of rapid changes in employment patterns, there is a need for a preventive maintenance system of human resource programs to mitigate fear, hardship, and inefficiencies. Included in this public system would be programs to gather and disseminate up-to-date job information, as well as to provide job counseling. The federal government can also analyze and forecast labor demand patterns, as well as publicize the associated job requirements. It can also assist the adjustment process by actually financing occupational retraining and educational upgrading opportunities for adults. There are major institutional barriers that confront individuals who must re-adjust to changing employment conditions on their own. First, the personal financial cost of acquiring new training and additional education can be substantial. Secondly, there is often a lack of appropriate adult training and educational facilities in local areas that are in tune with national labor market needs. And thirdly, there is a lack of assurance that, if an individual has to make an unassisted new career decision, and undertakes a lengthy retraining process, new opportunities will actually be available.

An ideal preventive maintenance system would also include a comprehensive program to facilitate labor mobility from areas of worker surplus to areas of labor scarcity. Voluntary relocation programs are part of human resource initiatives in Western Europe, but they have not passed the pilot experimental stage in the United States. The resistance to such efforts is political, not economic. Because of the "oneman, one vote" principle that allocates political power, politicians are loathe to support programs to move their constituents to other political jurisdictions no matter how serious their employment needs. In contrast, politicians are willing to support almost any endeavor to attract industry to their jurisdictions (for instance, "enterprise zones," tax abatements, the issuance of industrial bonds, and the creation of industrial parks) but will oppose most efforts to move workers out. Often the efforts to attract new industries are unsuccessful, or insufficient, or the new industries bring their workers with them and only "cream" the local labor supply for new hires. The needy workers of the local area, therefore, are often left with the prospect of seeking some form of income maintenance or of relocating elsewhere on their own. When workers who are not in the higher occupational echelons relocate on their own initiative, the decisions are frequently made on the basis of kinship ties rather than as a response to demonstrated labor shortages. A guided relocation program would involve the use of trained experts to screen and to refer for voluntary interstate transfer those workers 
who can fill job vacancies in localities where jobs actually exist. Such a process can eliminate much of the waste, hardship, and disorderly search for new jobs that confront some workers who have been dislocated from their former employment.

In each of the above instances, the justification for public interventions is based on the belief that they can enhance the actual workings of the labor market. The process does not counter revealed market conditions but, rather, serves to facilitate the efficiency of the adjustment process by addressing the institutional obstacles.

Long-Run Educational Development. Ultimately, the foundation of a human resource strategy for a rapidly changing economy must be built on the quality of the nation's overall education system. As one study of the economic implications of the computer age concluded in 1983, "a highly literate work force, not necessarily college-trained, is precisely what is needed for worker flexibility and adaptability in the post-industrial society, with its ever more rapidly changing circumstances." 47 The study noted that what is often overlooked in discussions of Japan's emphasis on education is that their primary and secondary education system is not intended to create an educational elite but, rather, to generate a high average level of capability throughout their society.

It is not necessary at this juncture to detail the litany of indictments contained in the studies that have catalogued the serious failures of the contemporary U.S. educational system. ${ }^{48}$ Blame for the past is less important than responsibility for the future. The extensive institutional reforms that are needed, however, involve far more than the public expenditure of increasing sums. They entail major educational changes in teacher preparation, compensation, and certification; in administrative practices and the distribution of decision-making power; in curriculum development; in disciplinary practices; and in academic standards for assessing student performance and promotion. They also involve the need for greater emphasis on "drop-out" prevention, as well as the need to provide lifetime educational opportunities that are accessible for more adults. And, they include the necessity to make access to education at all levels contingent on the ability to learn and not on the ability to pay. In other words, extensive institutional changes are essential if education is to contribute to the answer and not worsen the problem of contemporary labor force adjustment.

Any serious effort to reform the nation's education system so that it can become congruent with meeting long-term economic needs must ultimately be linked to some degree of national economic planning. To 
this end, there is an implicit need for the adoption of an overall industrial policy for the nation of which education and training policies would be a vital component. ${ }^{49}$ Although the topic is controversial, there can be little purposeful long-term educational preparation of the labor force for employment if there is little direction provided as to where the economy is thought to be going.

Equal Employment Opportunity. The discussion of human resource development up to this point has been predicated on the assumption that qualified workers will have equal access to job openings. Experience, however, has demonstrated that it cannot be realistically assumed that labor markets function solely on the basis of merit and productivity. It has also been revealed that the roots of discrimination run deep into the institutional practices that prepare workers to compete in the labor market. Hence, mechanisms to monitor employment practices and patterns and to redress wrongful actions must be a fundamental component of any serious human resource development strategy. Without these assurances, there is little logic in public efforts to develop the human resource potential of significant segments of the labor force.

Although there is no dispute among economists over the principle that workers should be employed on the basis of their productive capabilities and not their personal characteristics, there has been extensive disagreement over what constitutes discrimination and how extensive an issue it is. The perception of the nature of the issue, as well as the assessment of its magnitude, are important because they define the nature of the appropriate remedies and determine the degree of importance to be assigned to the problem.

Until the late 1950 s, neoclassical economics essentially ignored the issue of employment discrimination in the labor market. In a competitive environment, employment discrimination is an irrational act and the theory assumes rational behavior. But during these same years, as the conditions were occurring that would spawn the civil rights movement, Gary Becker introduced a refinement of neoclassical theory. ${ }^{50} \mathrm{He}$ conceded that some employers may have "a taste for discrimination" that may be reflected in their employment decisions. This "taste," however, is seen to be an entirely exogenous factor that is beyond the purview of economic analysis. There is no indication as to what creates it or what forces perpetrate it. Becker's analysis was welcomed by neoclassical theorists because it implied that, if discrimination is eradicated, labor markets will function in their assumedly competitive manner. Becker, however, defined discrimination in a very limited way: it existed only in those circumstances where two workers of a 
different race (or any other arbitrary distinction) who both have equal productivities are paid differently. If productivities differ, then there is no discrimination, since rewards are merely reflecting differential human capital endowments. Becker's analysis, therefore, was more a theory of wages than a theory of discrimination.

Numerous major refinements were soon offered by other neoclassical economists. ${ }^{51}$ These refinements, however, revealed considerable disagreements. As Ray Marshall has noted "they [that is, neoclassicalists] agree only on the form of the theory, not on the details or even the major conclusions." 52

By far, the most complete statement of the revised neoclassical theory was offered by Kenneth Arrow. ${ }^{53}$ Essentially, Arrow rejected the idea of "tastes for discrimination" and instead introduced the notion of "statistical discrimination" as the explanation for continuing racial and gender differences in the labor market. That is to say, employers use group characteristics as a proxy for individual characteristics. Initial differences in productivities could be taken as a given and reinforced over time to become a "perception of reality." But what is the basis of these "beliefs"? Arrow suggested cognitive dissonance. But as Marshall notes, it is difficult to see how beliefs in a supposedly rational paradigm could persist if they were merely perceptions of reality that experience demonstrated to be erroneous. Likewise, the revised theory does not give any indication about what gives discriminators the power to discriminate in a competitive market system. Presumably there must be in a competitive system at least one employer who would act rationally and not practice discrimination. If so, such an employer would drive all firms who practice discrimination out of business. For these and other reasons, there are really no useful anti-discrimination policies that flow from the revised neoclassical model. Accordingly, the neoclassical model has rendered no contribution to real-world efforts to address one of the major labor market issues of this generation.

Neoclassical theory makes no distinction between overt and covert discrimination. It ignores completely the consequences of discrimination that occur when institutional practices deny equal access to jobs, training, and information to certain subgroups of the labor force. As a consequence, those groups that are discriminated against may not have the opportunity or may not aspire to seek the necessary skill and educational requisites. It was these practices that the National Advisory Commission on Civil Disorders unanimously found in 1968 to be the principle barrier confronting the integregation of blacks into the economic mainstream. ${ }^{54}$ Similar claims have been made about the obsta- 
cles that confront other racial minorities in particular and women in general. By failing to stress the difference between overt discrimination and institutional discrimination, it is possible that discriminators can practice covert discrimination while claiming to be objective in their employment decisions.

When the Civil Rights Act of 1964 was passed, it, too, incorporated a perception that the problem of discrimination was manifested only through overt actions. Discrimination was viewed as being unambiguous. Hence, when passed, the Act was written in language that simultaneously sought to outlaw discriminatory actions while trying to protect the rights of employers to choose the most qualified labor force available, as well as to protect the job security rights of present employees. The gross inadequacies of this perception of both the problem and the scope of the appropriate remedies were soon revealed by the outbreak of civil disorders in urban centers across the nation in the mid-1960s. They occurred at a time when aggregate unemployment was considerably lower (in the mid-3 percent range) than it has been ever since. The message was clear: equal employment opportunity meant more than simply full employment-the sine qua non of neoclassical, Keynesian, and monetarist paradigms. It meant that there had to be changes in the racial and gender composition of employment patterns, as opposed to an exclusive policy focus merely on the level of employment. As a black leader once expressed it: "after all, we had full employment back on the plantations."

The finding of the Commission on Civil Disorders was that "white racism" as manifested by institutional discrimination was the chief barrier to the attainment of equal employment opportunity. This conclusion opened an entirely new policy era with respect to the issue of employment discrimination. The findings were not original, as other scholars (especially in sociology and psychology) had earlier made the same point. But the fact that a national commission composed entirely of political moderates could so boldly and clearly make the charge gave credence to the proposition. ${ }^{55}$ It meant that a declaration of words to prohibit labor market discrimination would not suffice to provide equal employment opportunity. Labor market interventions would be required.

Although the Commission spoke only of the predicament of blacks, the message to varying degrees applied to other groups that had also sustained discrimination. The heritage of past denial of opportunities raises difficult questions such as stifled occupational aspirations, the effects of unequal educational quality, the absence of labor market in- 
formation channels, the lack of opportunity to acquire skills in the newer and more technologically-oriented industries and the expanding managerial and professional occupations, and the paucity of formal job credentials. As for the actual implementation of equal employment opportunity at the work site, institutional discrimination raised difficult questions concerning recruitment, screening, and training practices of employers. Many of these practices were viewed by employers as legitimate methods to attract, cull, and prepare a qualified labor force. Thus, as Peter B. Doeringer and Michael Piore have warned, "the inherent equity of an attack upon racial discrimination is not always as clear to those within the market as it is to outsiders, and efforts to eliminate racial discrimination are often viewed by the employers and employees as an assault upon the instruments which effect labor market adjustment and preserve job security." 56 The process of actually securing changes in employment practices, therefore, has proven to be both difficult and slow.

Without diverting into a lengthy discussion of how equal employment opportunity policy has evolved, it suffices to say that by the mid-1980s it has reached a crossroads. Equal employment opportunity policy, as manifested by the development of affirmative action programs, has always been premised on the assumption that qualified workers from previously excluded groups do exist. Public policy can only ask that job credentials be job-related and that employment practices be fair. For many women and for some minorities this is all that has been necessary to open up employment opportunities where they previously did not exist. It is essential that these efforts continue, as it is unlikely that the principles of equal employment opportunity have yet been fully institutionalized to the degree that they can be taken for granted. On the other hand, until the lingering human resource development issues addressed elsewhere in this essay are fully supported and funded, it is unlikely that significant changes in racial employment patterns are going to occur. In fact, there is ample reason to fear that they are going to deteriorate.

\section{The Final Dimension}

The aforementioned themes have sought to highlight the critical role that human resources assume in the development of industrial societies in general and in the United States in particular. They have also focused upon programmatic efforts to assure that the latent abilities of the work force are given the opportunity to be developed and to be impartially 
employed. But the accomplishment of these tasks will be of little consequence if there is not parallel concern for the type of world in which these endeavors are an evolving part.

The goal of human resource development should be to provide opportunities for individuals to become better informed-in the sense both of one's personal ability to be prepared for employment and one's broader awareness of the quality of the society of which he or she is a part. The nation is entering a period of economic revolution in the means and methods of production. The answers to the problems of the past appear to have little relevancy to those of the present. The same can be said for the relevancy of past academic paradigms depicting the operation of the economy. The pressure to use science as a form of innovation and to encourage the technological application of the ensuing outcomes is not coming from the competitive sectors of the economy. Instead, the generative forces stem primarily from the oligopolistic private sector, the public sector at the federal level (especially as manifested by its expenditures on advanced forms of defense weaponry) and, the quasi-public support given by the federal government to private profit and non-profit enterprises for scientific research and development. As Robert Heilbroner has noted, the spectacular growth since World War II in scientific discovery and technological application "is no longer a spontaneous product of market forces." ${ }^{57}$ Perceptively, he warns that "the idea that technology is benign in its social impact may be the most tragic of all contemporary faiths." 58 Technology and science have become commanding realities that are reshaping the relationship of human beings to their natural environment. Educational institutions, in addition to their vocational mission, must inspire labor force participants to pursue life-long self-education, as well as to transmit the obligation to their leaders to require that the forces of science and technology be used for tolerant, compassionate, and peaceful purposes. It is imperative that the uses of these forces be the result of decisions made by an informed citizenry and not by an opinionated or indifferent society. Otherwise, the progression of industrialization could lead to calamitous human consequences. As Carlo Cipolla has warned, "the mass schools of the industrial world tend to teach techniques that leave the spirit barren." 59 He adds that "there is nothing more dangerous than technical knowledge when unaccompanied by respect for human life and human values." 60 As one witnesses the advent of genetic engineering, robotics, nuclear power, genetic screening, artificial intelligence, laser-based weaponry, and space stations (to recite only a few science-based technologies) into societies that are still domi- 
nated by intolerance and aggressiveness, there is justifiable reason for alarm.

If human resources are truly "the wealth of nations," their development carries with it the parallel responsibility to recognize that their contribution to the economy must enhance the quality of life on this planet and not lead to its enslavement, impoverishment, or extinction.

1. Frederick H. Harbison, Human Resources as the Wealth of Nations (New York: Oxford University Press, 1973).

2. Ray Marshall, "The Role of Appprenticeship in an Internationalized Information World." Paper presented at the Conference on Learning By Doing sponsored by The International Union of Operating Engineers, the U.S. Department of Labor, and Cornell University. Albany, New York, 6 April 1986, p. 1.

3. John R. Commons, Institutional Economics: Its Place in Political Economy, Vol. 2 (Madison: University of Wisconsin Press, 1961), Chap. 10.

4. John M. Keynes, The General Theory of Employment, Interest and Money (New York: Harcourt Brace and Company, 1958).

5. See, Theodore W. Schultz, "Investment in Human Capital," American Economic Review 51 (March, 1961): 1-17; Theodore W. Schultz, Investing in People: The Economics of Population Quality. (Berkeley: University of California Press, 1981); and Gary Becker, Human Capital (New York: National Bureau of Economic Research, 1964).

6. Michael J. Piore, "The Importance of Human Capital Theory to Labor Economics-A Dissenting View." Proceedings of the 26th Annual Winter Meetings (Madison: Industrial Relations Research Association, 1973), p. 253.

7. See, for example, Eli Ginzberg, "Expanding the Knowledge Base for Informed Public Policy" in Employment and Training R\&D, ed. R. Thayne Robson, (Kalamazoo, Michigan: The Upjohn Institute for Employment Research, 1984), p. 3; See also Gunnar Myrdal, Objectivity in Social Research (New York: Pantheon Books, 1969).

8. David M. Gordon, Theories of Poverty and Underemployment (Lexington: D.C. Heath and Company, 1972) Chap. 3 and Peter B. Doeringer and Michael Piore, Internal Labor Markets and Manpower Analysis (Lexington: D.C. Heath and Company, 1971), Chap. 2.

9. For example, see Bennett Harrison, Education and Training in the Urban Ghetto (Baltimore: The Johns Hopkins University Press, 1972), Chap. 1; Ivar Berg, Education and Jobs: The Great Training Robbery (Boston: Beacon Press, 1971) Chapters 2,3 and 9; Gordon, Theories of Poverty and Un- 
deremployment, Chap. 4; and Doeringer and Piore, Internal Labor Markets, Chap. 2.

10. Compare Lester C. Thurow, Investment in Human Capital (Belmont, Calif.: Wadsworth Publishing Co., 1970) with Lester C. Thurow, Dangerous Currents: The State of Economics (New York: Random House, 1983), Chap. 7.

11. Thurow, Dangerous Currents, p. 180.

12. For example, see Ray Marshall, Vernon M. Briggs, Jr., and Alan King, Labor Economics: Wages, Employment, Trade Unionism, and Public Policy (Homewood, Ill.: Richard D. Irwin, 1984), 5th ed., Chap. 12.

13. Edward F. Denison, Trends in American Economic Growth, 1929-1982 (Washington, D.C.: The Brookings Institution, 1985).

14. Anthony Carnevale, Human Capital: A High Yield Corporate Asset (Washington: American Society for Training Directors, 1983).

15. Eli Ginzberg, “The Mechanization of Work," Scientific American 247 (September 1982): 66-75; Howard Fullerton and John Tshetter, "The 1995 Labor Force: BLS's Latest Projections," Monthly Labor Review 108 (November 1985): 17-25; Ray Marshall, "Labor Market Implications of Internationalization," in The Internationalization of the U.S. Economy: Its Labor Market Policy Implications, ed. Vernon M. Briggs, Jr., (Salt Lake City: Olympus Publishing Company, 1986) pp. 1-27; Joyanna Moy, "Recent Trends in Unemployment and the Labor Force, 10 Countries," Monthly Labor Review 108 (August 1985): 13-14; Philip Rones, “An Analysis of Regional Employment Growth 1973-1985,” Monthly Labor Review 109 (July 1986): 3-14; Carol Leon, "Occupational Winners and Losers: Who Were They During 1972-80," Monthly Labor Review 105 (June 1982): 18-28; G. T. Silvestri and J. M. Lukasiewicz, “Occupational Employment Projections: The 1984-95 Outlook," Monthly Labor Review 108 (November 1985): 42-59; Vernon M. Briggs, Jr., "Employment Trends and Contemporary Immigration Policy," in Clamor at the Gates, ed. Nathan Glazer (San Francisco: Institute for Contemporary Studies, 1985), pp. 135-60; Robert W. DeGrasse, Military Expansion and Economic Decline, (Armonk, N.Y.: M.E. Sharpe, Inc. 1983).

16. Clair Brown, "Unemployment Theory and Practice: 1946-1980," Industrial Relations 22 (Spring 1983); 164-85.

17. See Walter Heller, "The Administration's Fiscal Policy," and Otto Eckstein, "Aggregate Demand and the Current Unemployment," in Unemployment and the American Economy, ed. Arthur M. Ross, (New York: John Wiley \& Son Inc. 1964), pp. 93-115, and 116-34, respectively.

18. See Milton Friedman, "The Role of Monetary Policy," American Economic Review 58 (March 1968): 1-17 and Milton Friedman, Capitalism and Freedom (Chicago: The University of Chicago Press, 1962), pp. 53-55.

19. See Milton Friedman and Walter Heller, Monetary vs Fiscal Policy (New York: W. W. Norton \& Co., 1969).

20. Charles C. Killingsworth, "The Fall and Rise of the Idea of Structural Unemployment," Proceedings of the 31 st Winter Meetings of the Industrial Relations Research Association (Presidential Address) (Madison, Wisconsin: Industrial Relations Research Association, 1979), pp. 1-13; and Ginzberg, "The Mechanization of Work," pp. 66-75. 
21. Charles C. Killingsworth, "Full Employment and the New Economics," Scottish Journal of Political Economy (February 1969): 1-27.

22. Keynes, The General Theory of Employment, Interest and Money, Chap. 18.

23. Ibid., p. 245.

24. For example, see Walter Heller, New Dimensions of Political Economy (New York: W. W. Norton \& Company, 1967) and Arthur M. Okun, The Political Economy of Prosperity (New York: W. W. Norton and Company, 1970), Chap. 2.

25. Charles Holt, The Unemployment-Inflation Dilemma: A Manpower Solution (Washington: The Urban Institute, 1971), Chaps. 5 and 6.

26. Howard Rosen, "An Administrator's Reflections," in Employment and Training $R \& D$, pp. 73-104.

27. For a review of these efforts, see Eli Ginzberg, ed., Employing the Unemployed (New York: Basic Books, 1980); see also John E. Schwartz, America's Hidden Success: A Reassessment of Twenty Years of Public Policy, (New York: W. W. Norton \& Company, 1983), pp. 44-58; and Robert Taggart, A Fisherman's Guide: An Assessment of Training and Remediation Strategies (Kalamazoo: The Upjohn Institute, 1981).

28. Vernon M. Briggs, Jr., "The Revival of Public Service Employment in the 1970s: Lessons for the 1980s." Proceedings of the 34th Winter Meetings of the Industrial Relations Research Association (Madison, Wisc.: Industrial Relations Research Association, 1982), pp. 258-65.

29. John L. Palmer and Isabel V. Sawhill, eds., The Reagan Record (Cambridge, Mass.: Ballinger Publishing Company, 1984).

30. Leon F. Bouvier, The Impact of Immigration on the Size of the U.S. Population (Washington, D.C.: Population Reference Bureau, 1981), p. 1.

31. Vernon M. Briggs, Jr., Immigration Policy and the American Labor Force (Baltimore: The Johns Hopkins University Press, 1984).

32. For definitional details and a review of the major policy issues surrounding these definitions, see National Commission on Employment and Unemployment, Counting the Labor Force (Washington: U.S. Government Printing Office), 1979.

33. For example, see Harrison, Educational and Training in the Urban Ghetto; and Vernon M. Briggs, Jr. "The Rural Labor Force, Unemployment and Underemployment Issues" in The Economic Evolution of Rural America, both published in Hearings before the Subcommittee on Agriculture and Transportation of the Joint Economic Committee of the U.S. Congress (Washington, D.C.: U.S. Government Printing Office, 1985), pp. 226-27.

34. Sar A. Levitan and Robert Taggart, Employment and Earnings Inadequacy (Baltimore: The Johns Hopkins University Press, 1974) and Robert Taggart, Hardship: The Welfare Consequences of Labor Market Problems (Kalamazoo, Mich.: The Upjohn Institute for Employment Research, 1982).

35. Briggs, Immigration Policy, Chap. 8.

36. See, Robert Haveman and Daniel Saks, "Transatlantic Lessons for Employment and Training Policy," Industrial Relations 24 (Winter 1985): 20-36; Bernard Casey and Gert Bruche, "Active Labor Market Policy: An International Overview," Industrial Relations 24 (Winter 1985): 37-61; 
and National Council on Employment Policy, Comparative Labor Market Policies of Japan, West Germany, United Kingdom, France and Australia, ed. Howard Rosen (Salt Lake City: Olympus Press, 1985).

37. See Charles C. Killingsworth, "Automation, Jobs, and Manpower: The Case for Structural Unemployment," in The Manpower Revolution, ed. Garth L. Mangum (Garden City, N.Y.: Doubleday \& Company, 1966), pp. 97-1 16. See also, Garth L. Mangum, The Emergence of Manpower Policy, (New York: Holt, Rinehart and Winston, 1969).

38. The studies are cited in Jonathan Kozol, Illiterate America, (Garden City, N.Y.: Anchor Press/Doubleday, 1985), pp. 7-12.

39. Ibid. (see citations in the "Notes" section on p. 227).

40. National Commission on Excellence in Education, Nation at Risk: The Imperative for Educational Reform, A Report to the U.S. Department of Education (Washington, D.C.: U.S. Government Printing Office, 1983).

41. "Hearings Accents Problem of Work Force Illiteracy," Daily Labor Reporter, No. 149 (2 August 1985), p. A-10.

42. Ibid.

43. Briggs, Immigration Policy, p. 159-66 and 220-22; and Ellen Sehgal, "Foreign-Born Workers in the U.S. Labor Market: A Special Survey," Monthly Labor Review 108 (July 1985): 18-24.

44. "Hearings Accents Problem of Work Force Illiteracy."

45. "Service Sector is Diverse, BLS Chief Says," Daily Labor Reporter, No. 75 (18 April 1986), p. A-6.

46. Ibid.; see also Leon, "Occupational Winners and Losers."

47. Edward A. Feigenbaum and Pamela McCorduck, The Fifth Generation: Artificial Intelligence and Japan's Computer Challenge to the World, (Reading, Mass.: Addison-Wesley Publishing Company, 1983), p. 147.

48. National Commission on Excellence in Education, Nation at Risk; see also Thomas Sizer Horace's Compromise: The Dilemma of American High Schools (Boston: Houghton Mifflin Co., 1984); National Board of Inquiry, Barriers to Excellence: Our Own Children at Risk (Boston: National Coalition of Advocates, 1985); Association of America Colleges, Integrity of the College Curriculum (Washington, D.C.: Association of American Colleges, 1985); Ernest L. Boyer, High School: A Report on Secondary Education in America (New York: Harper \& Row, 1983); National Institute of Education, Excellence in American Higher Education (Washington, D.C.: National Institute of Education, 1984); National Science Board, Commission on Precollege Education in Mathematics, Science and Technology, Educating Americans for the 21st Century, (Washington, D.C.: National Science Board, 1983); National Commission on Student Financial Assistance, Signs of Trouble and Erosion: A Report on Graduate Education in America (Washington, D.C.: National Commission on Student Financial Assistance, 1983).

49. R. D. Norton, "Industrial Policy and American Renewal," Journal of Economic Literature 24 (March 1986): 1-40. See also Robert R. Reich, The Next American Frontier (New York: The New York Times Book Co., 1983).

50. Gary S. Becker, The Economics of Discrimination (Chicago: University of Chicago Press, 1957 [1971]). 
51. For the most comprehensive review of this literature, see Ray Marshall, "The Economics of Racial Discrimination: A Survey," The Journal of Economic Literature 12 (September 1974): 849-71. See also Ronald L. Oaxaca, "Theory and Measurements in the Economics of Discrimination," in Equal Rights and Industrial Relations, ed. Leonard J. Hausman, et al (Madison, Wisc.: Industrial Relations Research Association, 1977) pp. $1-30$.

52. Marshall, "The Economics of Racial Discrimination," p. 849.

53. Kenneth J. Arrow, "Models of Job Discrimination" and "Some Models of Race in the Labor Market," Chaps. 2 and 6, in Racial Discrimination in Economic Life, ed. A. H. Pascal, (Lexington, Mass: D.C. Heath, 1972).

54. National Commission on Civil Disorders, Report of the National Advisory Commission on Civil Disorders, (New York: Bantam Books, 1968).

55. Vernon M. Briggs, Jr. "The Report of the Commission on Civil Disorders: A Review Article," Journal of Economic Issues 2 (June 1968): 200-210.

56. Doeringer and Piore, Internal Labor Markets and Manpower Analysis, p. 136.

57. Robert L. Heilbroner, "The Impact of Technology: The Historic Debate," in Automation and Technological Change, ed. John T. Dunlop (Englewood Cliffs, N.J.: Prentice Hall, 1962), p. 22.

58. Ibid., p. 25.

59. Carlo Cippola, The Economic History of World Populations (Baltimore: Penguin Publications, 1962), p. 109.

60. Ibid., p. 117 